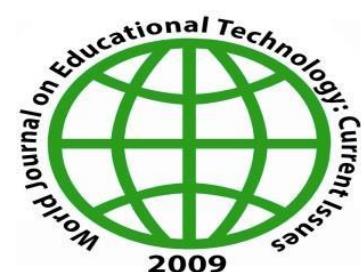

www.wj-et.eu

\title{
Synchronous collaborative writing instruction in a university EFL context: Challenges and solutions
}

Panachanok Chanwaiwit a *, Mae Fah Luang University, School of Liberal Arts, Chiang Rai, 57100, Thailand, http://orcid.org/0000-0002-1655-2147

Bhornsawan Inpin b, Mae Fah Luang University, School of Liberal Arts, Chiang Rai, 57100, Thailand, https://orcid.org/0000-0002-1526-5269

\section{Suggested Citation:}

Chanwaiwit, P., \& Inpin, B. (2021). Synchronous collaborative writing instruction in a university EFL context: Challenges and solutions. World Journal of Educational Technology: Current Issues. 13(4), 721-739. https://doi.org/10.18844/wjet.v13i4.6259

Received from August 25, 2021; revised from September 26, 2021; accepted from October 12, 2021. Selection and peer review under responsibility of Prof. Dr. Servet Bayram, Yeditepe University, Turkey. ${ }^{\circ} 2021$ Birlesik Dunya Yenilik Arastirma ve Yayincilik Merkezi. All rights reserved.

\section{Abstract}

This study explored EFL instructors' perceptions and practices to identify challenges of teaching synchronous collaborative writing $(\mathrm{SCW})$ and then proposed solutions to the problems. The instructor survey of practices in online English writing instruction was sent to 52 instructors from 15 regional universities in Thailand; 51 responded to the survey and, after selection, 24 participants were included. Data also included classroom observations and interviews. The participants felt unprepared to teach SCW because of insufficient online pedagogical skills in engaging students in the classroom and a lack of technology skills in managing online classrooms, facilitating real-time collaborative writing and giving objective formative assessments. The findings suggest that EFL instructors improve their teaching quality regarding student engagement, goals, content, tools, classroom management strategies, instructor and student roles, SCW activities and assessment. These discoveries enable educators to develop contextualised guidelines for SCW practices and suggest initial preparation for EFL cyber education.

Keywords: Online learning challenges, synchronous collaborative writing, EFL writing teaching practices, EFL writing instruction.

\footnotetext{
* ADDRESS FOR CORRESPONDENCE: Panachanok Chanwaiwit, School of Liberal Arts, Mae Fah Luang University, Chiang Rai, 57100, Thailand E-mail address: chanwaiwit@gmail.com
} 


\section{Introduction}

Due to the coronavirus disease 2019 (COVID-19) outbreak, English as a Foreign Language (EFL)/English as a Second Language (ESL) writing instructors have turned their traditional offline classrooms into online classrooms to maintain physical distancing. The COVID-19 situation has motivated them to reconstruct their teaching practices to ensure that they are effective and practical for their students (Adara \& Onin, 2020; Bao, 2020; Murphy, 2020; Noor et al., 2020). In the post-pandemic world, effective instruction requires instructors to have online pedagogical content knowledge, assessment skills and, most importantly, effective teaching strategies to engage students in the classrooms (Alghamdi et al., 2021).

In addition, informed by sociocultural theory, writing has shifted from being cognitive and individual to being interactive and social. This is because, in current workplaces, writing is often completed in teams rather than individually (Storch, 2019). Another important reason is that several online tools for the collaborative creation of texts, such as Google Docs and wikis, have changed literacy practices and made team writing easier and more productive (Alwahoub et al., 2020). Therefore, writing instruction should focus on the importance of peer interaction and language development (Li, 2018). Also, online collaborative writing $(\mathrm{CW})$ tends to be more beneficial in preparing EFL students for future careers.

Online CW instruction involves two modes of learning: synchronous and asynchronous. Instructors may include the two learning modes in their instructional design models, but if they strictly use only one or the other, their instruction will affect the quality of learning differently.

A number of studies (e.g., Olesen, 2020; Sriwichai \& Inpin, 2018) have been carried out on hybrid (instructors teach remote and onsite students at the same time) or blended learning (students do some activities online and do others onsite). However, when everyone is under a stay-at-home order or when a Cyber University project is in need, blended/hybrid mode is impossible. Besides, asynchronous lessons are not sufficient for CW because when instructors and/or students write together online asynchronously, they are geographically and emotionally distant; direct contact in a synchronous online environment seems to offer stronger relationships and more interaction between instructor and students and among students (e.g., peer reviews and editing) (Xi \& Li, 2020). Krishnan et al. (2019) remark that CW is increasingly required in most academic and career settings in the 21st century and online SCW enables instructors to provide a variety of writing experiences to students. Therefore, using synchronous online delivery in teaching students $\mathrm{CW}$ is an interesting possibility for improving the quality of EFL writing instruction.

\subsection{Conceptual framework}

\subsubsection{Synchronous learning}

Synchronous learning refers to 'a learning modality that permits participants to communicate in realtime or nearly in real-time' [CCCC (Committee for Best Practices in Online Writing Instruction), 2013, p. 35]. Interactions occur via two-way voice, voice and video or chat-based scenarios. The great benefit of synchronous learning is that it makes students feel connected with their instructors and peers due to face communications presented in instruction. Students can have an active discussion, cooperation, immediate feedback, personal contact with the instructor and classmates and individual guidance (Sugino, 2021). For EFL learning, Ozdal et al. (2021) found that although online language learning was 
not as effective as in-person learning, students preferred synchronous learning to asynchronous courses because they offer a similar experience as face-to-face learning. However, Al-Nofaie (2020) expressed disagreement that EFL students in Saudi preferred the asynchronous mode to the synchronous one because of its flexibility. This demonstrates a major disadvantage of synchronous learning that instructors have to stick to an inflexible class schedule. Alahmari (2019) and Dahmash (2021) advise that, to facilitate students, all the class meetings and presentations be recorded so that students can download the recordings and study afterwards. Furthermore, Xi and Li (2020) found that while synchronous learning stimulates active interaction, students can be distracted by classmates. Therefore, instructors should be prepared and proactive; they should create a sense of instructor presence, establish a sense of community, encourage student collaboration, troubleshoot and follow practical guidelines.

Planning synchronous tools is very important for increasing students' productivity and efficiency. Whitney (2019) found that synchronous cloud-based instruction allows instructors to create an active learning environment that maximises student engagement; however, instructors must employ appropriate pedagogy to transfer knowledge, skills and competencies to their students through in-class communication, teamwork, discussion and instructor feedback.

Web 2.0 tools, such as social networking sites, Google Docs, blogs and wikis, for L2 writing pedagogy (Storch, 2019) have the potential to increase collaboration in synchronous classrooms. Learning management systems (LMS) can also be used in the synchronous classroom to build learning communities which promote collaboration, interaction and engagement (Ustun et al., 2021).

\subsubsection{Collaborative writing}

Whereas EFL students have been taught to write individually, new findings have led to a paradigm shift in writing instruction. The current schools of thought perceive writing as an interactive and social process (Storch, 2013). According to Storch (2013, p. 2), CW is when 'participants work together and interact throughout the writing process, contributing to the planning, generation of ideas, deliberations about the text structure, editing and revision'. CW is referred to as a social activity which is drawn by sociocultural theory/social constructivism and a process-oriented approach (Li, 2018). It involves several concepts such as scaffolding, zone of proximal development, community of practice and activity theory. It appears to have potential to drive change in students' knowledge, strategies and interest (Parkinson \& Dinsmore, 2019) which are crucial for EFL students' development.

In Sarkhosh and Najafi's (2020) study, it was found that CW made texts more fluent and accurate in the short and long term. Students can provide useful grammatical feedback to their team, negotiate and scaffold each other. However, Storch (2019) found that some ESL/EFL instructors feel reluctant to implement CW activities because of the perception of writing as a solitary activity and because of the assessment practices that measure individual accomplishment. Some instructors lack awareness of the affordances of CW for students' English learning. Some do not know how to implement CW activities effectively. Alford (2019) argues that instructors' English proficiency and past literacy experiences influence their beliefs and self-efficacy as writing instructors; their negative writing experiences may damage their confidence to teach writing and their negative teaching experience may affect their perceptions and practices. In Coffin's (2020) study, EFL instructors reported that CW has led to many complaints from students about unfair work contribution and students were not likely to engage in class activities. 
In the last decade, technology has become an educational trend in CW because it can tackle both teaching and learning problems. Alwahoub et al. (2020) reviewed $40 \mathrm{CW}$ articles from 2011 to 2019 and found that, in SCW classrooms, Google Docs is the most common tool in Web 2.0 and SCW could improve individual writing performance and abilities because collaborators had more positive attitudes towards writing than individuals. Furthermore, Abrams (2019) found that, in her creative writing course using Google Docs, CW groups produced more propositional and coherent texts than less-collaborative groups. Zhang and Zou (2021) concluded from their study that technologies allow students to reflect on their work, learn from others, interact with team members easily and motivate them to write. They also added that technologies will be effective only when they are easy to use, when students actively engage in planning and reflection and when students are responsible for co-authoring.

\subsubsection{Synchronous collaborative writing (SCW) instruction}

SCW is a 'social and technical act of real-time planning, drafting and revising a text with others using a digital writing platform' (Krishnan et al., 2019, p. 2). SCW instruction is a writing pedagogical practice that requires students, who are in different places but are online on the same system at the same time, to share linguistic knowledge, responsibility and ownership while interacting, co-authoring, peerreviewing and editing a paragraph.

Yim and Warschauer (2017) investigated an SCW classroom and found that the roles of instructors in synchronous environments are closely associated with their teaching practices and have a great impact on students' writing achievement. In the SCW classroom, students can access online writing resources and learn from others; these activities may be prohibited in a traditional learning environment.

SCW instructors can use e-rubrics to attach and grade students' assignments in Google Classroom. Students can get feedback from the instructor more quickly than traditional grading using a pen; immediate feedback can help to reinforce knowledge and promote the flow of learning. Erguvan and Aksu (2021) found that, after using e-rubrics, writing instructors accepted that e-rubrics facilitate scoring, reduce student complaints and confirm standardisation.

Instructors can adopt technologies (e.g., text mining tools) for objective and transparent assessment to assess individual textual contributions to a CW task; the free-rider problem that cannot be identified in a traditional writing classroom can be reduced. The results can also reveal a group or individual's writing process, written product and progress that instructors can then scrutinise to adjust their instruction for re-teaching and remediation in real time. Kitjaroonchai and Suppasetseree (2021), who studied the use of a text mining tool, namely DocuViz, to visualise students' CW behaviours while writing an essay in Google Docs, found that personal goals and team roles influence students' contribution and unequal and non-mutual engagement in task negotiation may be caused by students' low-level proficiency and negative attitudes towards collaborative task. In Steinberger's (2017) study, the findings suggested that instructors be aware of legal and ethical issues when implementing SCW. In addition, he suggests that shared documents (e.g., Google Docs) be used to promote process-oriented assessment. Most importantly, the findings revealed that inexperienced instructors should receive guidelines on how to use shared documents to support SCW. Lastly, Krishnan et al. (2019) noted that SCW instructors' responsibilities are not limited to teaching students to write well in English, but also provide technical and social support to students. 


\subsection{Related research}

From the literature, current studies on EFL computer-mediated CW have focused mostly on four areas: learners' perceptions of online collaboration, processes of writing, writing products and interaction patterns. For SCW, it was found that previous studies (e.g., Abrams, 2019; Dahmash, 2021; Krishnan et al., 2019) directed attention to the justification of the claim that SCW is effective in helping students develop skills and attitudes towards writing. Therefore, in this study, we identified six core categories of problems that writing instructors may encounter when teaching SCW from some schemes that previous SCW studies had introduced (Table 1).

Table 1. Literature synthesis of SCW instructional challenges

\begin{tabular}{|c|c|c|}
\hline Core categories & Sub-categories & Description \\
\hline $\begin{array}{l}\text { Teaching self- } \\
\text { efficacy }\end{array}$ & $\begin{array}{l}\text { Adaptability } \\
\text { (Ma et al., 2021) } \\
\text { Teacher burnout (Denniston, } \\
\text { 2020) }\end{array}$ & $\begin{array}{l}\text { Lack experience; separation from students; } \\
\text { administration; students' poor performance } \\
\text { putting little effort in teaching }\end{array}$ \\
\hline $\begin{array}{l}\text { Instructional } \\
\text { planning }\end{array}$ & $\begin{array}{l}\text { Writing approach } \\
\text { (Krishnan et al., 2019) } \\
\text { Digital media (Cho, 2021) }\end{array}$ & $\begin{array}{l}\text { Focusing mainly on linguistic knowledge; lack social } \\
\text { support } \\
\text { Lack of media literacy to prepare for teaching and } \\
\text { solving technical problems }\end{array}$ \\
\hline \multirow[t]{2}{*}{$\begin{array}{l}\text { Learning } \\
\text { environment }\end{array}$} & $\begin{array}{l}\text { Classroom management } \\
\text { (Whitney, 2019) }\end{array}$ & Handling student behaviours and large class sizes \\
\hline & $\begin{array}{l}\text { Trust and safety (Yim \& } \\
\text { Warschauer, 2017) }\end{array}$ & $\begin{array}{l}\text { Unaware of the importance of building positive } \\
\text { relationships and community of practice. }\end{array}$ \\
\hline \multirow[t]{2}{*}{$\begin{array}{l}\text { Student } \\
\text { engagement }\end{array}$} & $\begin{array}{l}\text { Instructor's roles (Yim \& } \\
\text { Warschauer, 2017) }\end{array}$ & $\begin{array}{l}\text { Not fulfilling students' expectations; Reluctance to } \\
\text { implement CW activities }\end{array}$ \\
\hline & $\begin{array}{l}\text { Pedagogy } \\
\text { (Whitney, 2019) }\end{array}$ & $\begin{array}{l}\text { Non-interactive lectures; inactive and not meaningful } \\
\text { learning activities }\end{array}$ \\
\hline \multirow{3}{*}{$\begin{array}{l}\text { Instructional } \\
\text { delivery }\end{array}$} & Internet lag (Al-Nofaie, 2020) & Communication breakdowns \\
\hline & $\begin{array}{l}\text { Technical glitches (Cho, 2021) } \\
\text { Technical support (Yim \& } \\
\text { Warschauer, 2017) }\end{array}$ & $\begin{array}{l}\text { Power outages, data loss or temporary service loss } \\
\text { Insufficient technological infrastructure }\end{array}$ \\
\hline & Data privacy (Steinberger, 2017) & $\begin{array}{l}\text { Share documents; online activities; personal data are } \\
\text { gathered by commercial software or services. }\end{array}$ \\
\hline \multirow[t]{2}{*}{ Assessment } & $\begin{array}{l}\text { Product-oriented assessments } \\
\text { (Steinberger, 2017) }\end{array}$ & Little attention to writing process and development \\
\hline & Tools (Yim \& Warschauer, 2017) & Unfair judgement on group writing \\
\hline
\end{tabular}

\subsection{Statement of the problem}

Whereas SCW instruction has proven to offer great benefits to students' learning and writing achievements, there are concerns among EFL writing instructors who are inexperienced in its implementation, especially since the COVID-19 situation necessitated a sudden change from onsite to online instruction. According to the Committee for Best Practices in Online Writing Instruction (CCCC, 2013), the requirements for online writing instructors are that they must have high English proficiency, be able to teach writing skilfully and be able to teach writing in an online environment. However, the requirement of EFL university instructors' English proficiency, announced by the Ministry of Education (Thailand) (2015), is only at the intermediate user level of the Common European Framework of 
Reference. Moreover, misunderstanding about CW can prevent university EFL instructors from strengthening their writing instruction (Storch, 2019). Additionally, most university instructors are Generation X (26-39 years old) or Generation $Y$ (40-56 years old), who are learning to adjust to the technological change and trying to adapt to a world version 4.0. These factors can cause confusion and unpreparedness which can lead to poor quality SCW instruction. Besides, previous SCW research devoted attention to investigating students' collaborative practices and attitudes to identify the effects of SCW on students' development; studies on instructors' aspects are still rare, especially in EFL contexts. Thus, there was a strong need for exploration into the difficulties that EFL writing instructors were experiencing. Understanding the problems and their causes and determining solutions could facilitate writing instructors' teaching and develop a more effective writing experience for EFL students.

\subsection{Purpose of the study}

The purpose of this study is to explore how EFL writing instructors incorporated SCW instruction and what problems they encountered. This study narrowed down the scope of the investigation of EFL instructors' practices and focused on six aspects: teaching self-efficacy, instructional planning, learning environment, engagement, instructional delivery and assessment. The research questions are listed as follows:

1. What are EFL instructors' perceived challenges of online English writing instruction?

2. How do EFL instructors teach a synchronous collaborative English writing course?

3. What are the proposed solutions to the challenges of online EFL writing instruction?

\subsection{Significance of the study}

SCW is an effective way that EFL instructors can implement to prepare students for their career opportunities in the new normal. This study helps to broaden educators' understanding of barriers that hinder EFL instructors in their effort to teach SCW, which could develop a more practical writing experience for EFL students. The proposed solutions to the problems will directly benefit EFL writing instructors who feel reluctant to implement SCW in designing effective SCW instruction.

\section{Method}

\subsection{Research model}

This research used both quantitative and qualitative methods to develop a comprehensive understanding of challenges in SCW instruction. The research model is shown in Figure 1. 


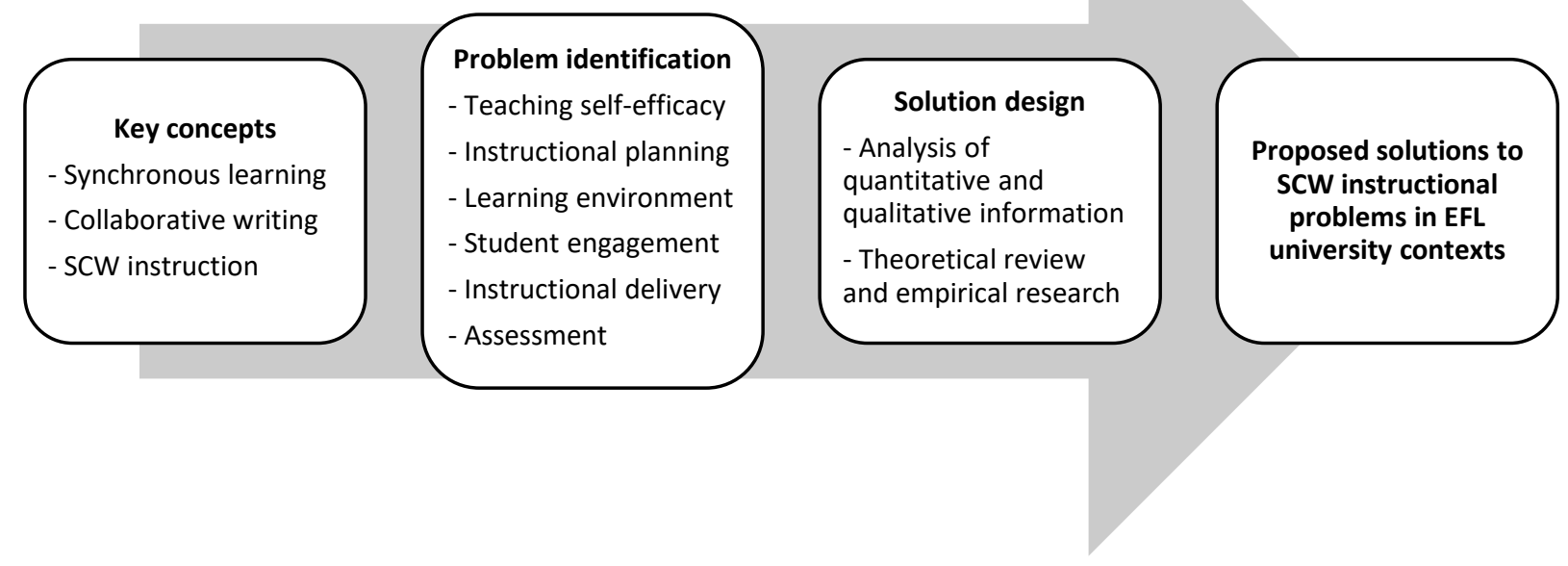

Figure 1. Research model

\subsection{Population and samples}

The population comprised 52 instructors, who were teaching English writing courses at 15 regional public universities in the 4 regions of Thailand, during the first semester of the academic year 2020. The population was determined from the instructors of English writing courses that the 15 universities provided for their English majors as the fundamental, core and required courses. The reason for selecting instructors from those universities was that the universities are located in the major cities outside Bangkok, the capital city of Thailand. They generally teach under similar conditions in terms of educational policy, university administration, students' academic background and technological support, especially in terms of Internet connection. The participant selection process was that we sent an online survey to 52 instructors. The survey was responded to by 51 instructors (Table 2).

Table 2. Demographics of participants in the survey $(n=51)$

\begin{tabular}{llcr}
\hline Category & Details & $\begin{array}{l}\text { Number of } \\
\text { respondents }\end{array}$ & Percentage \\
\hline Gender & Male & 28 & 54.90 \\
Age (years) & Female & 23 & 45.10 \\
& $21-30$ & 1 & 2.00 \\
& $31-40$ & 26 & 51.00 \\
Education & $41-50$ & 21 & 41.20 \\
& $51-60$ & 3 & 5.90 \\
\multirow{3}{*}{ Online teaching experience } & Bachelor's & 1 & 2.00 \\
\multirow{2}{*}{ Years of teaching English writing online } & Master's & 31 & 60.80 \\
& Ph.D. & 19 & 37.30 \\
& Yes & 38 & 74.50 \\
& No & 13 & 25.50 \\
& Mower than 3 years. & 14 & 36.80 \\
\hline
\end{tabular}


Precisely, 13 respondents had never taught online, but 38 respondents had. Those who had never taught online were asked to give reasons why they did not use this method of teaching. Additional recruiting criteria were used with the 38 instructors to gain more specific answers from the right respondents. There were 24 instructors who met the criteria of having at least 3 years of teaching experience and of teaching some English writing courses online. After selection, there were 24 participants who took part in the full survey.

Since every target university offered a paragraph writing course, the paragraph writing course was selected for classroom observations. The 13 instructors who taught this course in the first semester of the academic year 2020 were contacted to participate in the classroom observations. Only five instructors who had experienced implementing $\mathrm{CW}$ in their synchronous online classroom were recruited for classroom observations (Table 3).

Table 3. Demographics of the participants in the classroom observations and interviews $(n=5)$

\begin{tabular}{lccccc}
\hline & Instructor 1 & Instructor 2 & Instructor 3 & Instructor 4 & Instructor 5 \\
\hline Gender & Female & Female & Female & Male & Male \\
Age & 43 & 45 & 40 & 43 & 40 \\
Degree & Ph.D. & Ph.D. & Master's & Ph.D. & Master's \\
Teaching English writing & 10 years & 12 years & 11 years & 10 years & 11 years \\
Synchronous teaching & 1 year & 1 year & 1 year & 1 year & 1 year \\
\hline
\end{tabular}

\subsection{Data collection tools}

The three data collection tools employed in this study were all developed by the researchers based on the research framework and guided by 'Using Research Instruments: A Guide for Researchers' (Wilkinson \& Birmingham, 2003).

\subsubsection{Self-survey of practices in online English writing instruction}

The 31-question online survey comprised 5 closed-ended background questions (e.g., gender, age range, education), 24 four-point rating scale questions (Figure 2 ) asking the participants to indicate how frequently they displayed behaviours regarding 6 aspects (i.e., teaching self-efficacy, instructional planning, learning environment, engagement, instructional delivery and assessment) and 2 openended questions.

\begin{tabular}{|l|l|l|l|l|l|}
\hline No. & \multicolumn{1}{|c|}{ Items } & $\begin{array}{c}\text { Always } \\
\mathbf{( 7 6 - 1 0 0 \% )}\end{array}$ & $\begin{array}{c}\text { Often } \\
\mathbf{( 5 1 - 7 5 \% )}\end{array}$ & $\begin{array}{c}\text { Occasionally } \\
\mathbf{( 2 6 - 5 0 \% )}\end{array}$ & $\begin{array}{c}\text { Rarely } \\
\text { (1-25\%) }\end{array}$ \\
\hline 10. & $\begin{array}{l}\text { I feel that I have the English skills } \\
\text { required to teach English writing } \\
\text { effectively. }\end{array}$ & & & & \\
\hline
\end{tabular}

Figure 2. A 4-point-rating-scale question sample 


\subsubsection{Classroom observation checklist and field note form}

The form included two sections: the checklist and the field note. The form was developed to gather data for triangulation. The data were used to understand whether the instructors' practices were aligned with their perceptions. The checklist was used by the two observers to check whether the instructor did activities required for teaching SCW or not. The field note was used to record specific behaviours supporting the answers Yes or No. Each instructor was observed twice, 3 hours each time.

\section{Observation $\square 1 \quad \square 2$}

Instructor's Name:

Course: Number of Students:

Observation Date: Time:

\begin{tabular}{|l|l|l|l|l|}
\hline No. & \multicolumn{1}{|c|}{ Teaching Practices } & Yes & No & \multicolumn{1}{|c|}{ Actions } \\
\hline \multicolumn{1}{|l|}{ Learning Environment } & $\begin{array}{l}\text { The instructor creates and } \\
\text { maintains a stimulating, challenging, } \\
\text { and respectful classroom } \\
\text { environment and effective } \\
\text { classroom rules to encourage } \\
\text { collaboration. }\end{array}$ & & \\
\hline
\end{tabular}

Figure 3. Template of the classroom observation checklist and field note form

\subsubsection{Interview protocol}

The nine follow-up semi-structured interview questions were developed to gain in-depth information from the instructors about their perceptions and practices of synchronous writing instruction. The questions were grouped into three types: background questions, questions about the instructors' practices regarding the six aspects of the investigation and suggestions. The interview was carried out with the five instructors who gave permission for observations so that additional information about the instructors' practices of English CW could be included. 


\section{A. Background Questions}

1. Could you please tell me about your background and experience as an English writing instructor?

B. Questions about Synchronous Online Collaborative Writing Practices Teaching Self-Efficacy

2. How would you rate your knowledge and skills in teaching online English writing from 1 to 10 ? Why?

\section{Instructional Planning}

3. How do you usually plan your online synchronous writing instruction (e.g., teaching procedure, teaching materials, assignment, content, writing approach, assessments)?

Figure 4. Question samples of the interview

\subsection{Validity and reliability of the research instruments}

Three experts, holding Ph.D. degrees in Teaching English as a Foreign Language, Applied Linguistics and Computer Education and having more than 10 years of teaching experience in EFL university contexts, were invited to test the validity of the surveys by rating individual items of the surveys using the index of item-objective congruence (IOC) (Rovinelli \& Hambleton, 1977) and giving opinions on the clarity and suitability of each item. Then, the survey was tried out with 30 volunteers who were not participants in the study. The data collected were calculated to determine the reliability of the survey using Cronbach's alpha coefficient analysis (Brown, 2001). After the analysis, the Cronbach's alpha coefficient equalled 0.91, which was an acceptable value indicating that the survey was reliable. This demonstrates that the rating scale questions had high internal consistency.

The classroom observation checklist and field note form was validated by the three experts using the IOC. Then, the reliability of the form was determined by trying it out with two practice classroom observations ( 6 hours) of one instructor participant by the researcher and the co-observer under conditions similar to that of the main study. After that, Cohen's kappa statistic (Cohen, 1960) was used to test inter-observer reliability. After calculation, the kappa statistic was at 0.85 , which meant that there was a perfect inter-rater agreement or inter-rater reliability between the two observers.

The interview protocol was validated by the three experts. The $\mathrm{IOC}$ measure revealed that every item was valid. After that, three sample interviewees who were not included in the study were invited to pilot test the interview questions and give their opinions on the clarity and any modifications needed.

\subsection{Data collection}

After the research proposal, the research subject information sheet, the informed consent for instructors and students and the research instruments were approved by the university's Institutional Review Board; we contacted the gatekeepers at the 15 target universities and requested that their English writing instructors do the online self-survey. The qualified instructor's classroom activities were observed and recorded twice for a total of 6 hours. After the final examination of each observed class was finished, one researcher interviewed each instructor online for 30-45 minutes.

\subsection{Data analysis}

The data collected from the instructor self-survey responses, the classroom observation checklist and the student self-survey responses were analysed using the mean and standard deviation or percentage. 
The data obtained from the closed-ended questions of the survey were interpreted based on the following criteria: $3.50-4.00=$ their perception of practices in teaching and learning English writing online was at a high level, 2.50-3.49 = a moderate level, 1.50-2.49 = a low level and 1.00-1.49= the lowest level.

The data obtained from the observation checklist were interpreted based on the following criteria: 90-100 = instructors' teaching practices were at an excellent level, 80-89 = a very good level, 70-79= a good level, 60-69 = a satisfactory level, 50-59 = a sufficient level and 0-49= a poor level.

The open-ended survey questions, the observation field notes and the instructor follow-up interview transcripts were coded using open-coding and axial coding processes (Creswell \& Poth, 2016). The codes found were under the categories of teaching self-efficacy, instructional planning, learning environment, student engagement, instructional delivery and assessment.

\section{Findings and discussion}

\subsection{Instructors' perceived challenges of online English writing instruction}

Before collecting data from the instructors who satisfied the recruiting criteria, the 13 instructors who reported that they had never taught online, and were thereby excluded from the main survey, were asked to provide reasons why they did not teach online. Their answers were very similar and could be summarised by saying that they were afraid that their students might cheat or plagiarise by copying texts from websites and online resources. In addition, they perceived that writing is an individual task. If they had let students work together, they felt they could not have assessed students' writing performance and development accurately. They also perceived that the use of online resources and tools such as grammar checkers, paper graders and online editors prevented them from seeing students' real performance. More importantly, every instructor agreed that online writing instruction could not be compared with traditional face-to-face instruction. In addition, they were not confident enough to host a virtual classroom because they were unfamiliar with online tools. The results of the survey are shown in Table 4.

Table 4. Instructors' perceived levels of online writing teaching practices $(n=24)$

\begin{tabular}{lccl}
\hline Items & $\overline{\mathrm{x}}$ & $\mathrm{SD}$ & Meaning \\
\hline 1. Teaching self-efficacy & 3.24 & 0.37 & Moderate \\
2. Instructional planning & 3.40 & 0.18 & Moderate \\
3. Learning environment & 3.39 & 0.19 & Moderate \\
4. Student engagement & 3.23 & 0.19 & Moderate \\
5. Instructional delivery & 3.33 & 0.22 & Moderate \\
6. Assessment & 3.30 & 0.28 & Moderate \\
\hline Overall & 3.31 & 0.07 & Moderate \\
\hline
\end{tabular}

Table 4 reveals that the participant instructors perceived their practices in teaching English writing online at a moderate level $(\bar{x}=3.31, S D=0.07)$ in every aspect. There were two aspects that gained lower scores: student engagement $(\bar{x}=3.23, S D=0.19)$ and teaching self-efficacy $(\bar{x}=3.24, S D=0.37)$.

For teaching self-efficacy, the perceived practice that scored the lowest was 'dealing with technological issues, time constraints and large class sizes' $(\bar{x}=2.83, S D=0.48)$. For instructional planning, the lowest score was on 'using formative and summative student learning data in developing clear, sequencing and standard-based plans' $(\bar{x}=3.21, S D=0.51)$. For the learning environment, the lowest score went to 'encouraging students to give and receive constructive feedback to their peers' $(\bar{x}$ 
$=3.21, \mathrm{SD}=0.78$ ). For student engagement, the lowest score was on 'encouraging collaborative behaviours by promoting dialogic engagement using a variety of teacher pedagogical dialogues' $(\bar{x}=$ $3.00, S D=0.72$ ). For instructional delivery, the lowest score was on 'using teaching theories or strategies that are suitable for the nature of the online environment and the opportunities it provides to present explicitly and skilfully' $(\bar{x}=3.08, S D=0.72)$. For assessment, the lowest score was on 'using technologies for objective and transparent assessment of individual textual contributions to a group writing task' $(\bar{x}$ $=3.04, \mathrm{SD}=0.69$ ).

Table 5. Instructors' perceived challenges of teaching English writing online

\begin{tabular}{|c|c|c|c|c|c|}
\hline Core categories & Instructor no. & Total & $\%$ & Sub-categories & Description of challenges \\
\hline $\begin{array}{l}\text { Teaching self- } \\
\text { efficacy }\end{array}$ & - & - & - & - & - \\
\hline \multirow[t]{2}{*}{$\begin{array}{l}\text { Instructional } \\
\text { planning }\end{array}$} & $\mathrm{i} 14, \mathrm{i} 22, \mathrm{i} 24$ & 3 & 12.00 & $\begin{array}{l}\text { - Students' } \\
\text { English } \\
\text { proficiency }\end{array}$ & $\begin{array}{l}\text { - Dealing with students' diverse } \\
\text { English proficiencies }\end{array}$ \\
\hline & & & & - Tasks & - Designing online writing tasks \\
\hline $\begin{array}{l}\text { Learning } \\
\text { environment }\end{array}$ & $i 1, i 4, i 8, i 20$ & 4 & 16.00 & $\begin{array}{l}\text { - Classroom } \\
\text { management }\end{array}$ & $\begin{array}{l}\text { - Managing large classes and students' } \\
\text { improper behaviours }\end{array}$ \\
\hline \multirow[t]{2}{*}{$\begin{array}{l}\text { Student } \\
\text { engagement }\end{array}$} & $\begin{array}{l}i 1, i 2, i 3, i 5, i 7, \\
i 9, i 10, i 11, i 12, \\
i 13, i 16, i 18, \\
i 20, i 21, i 23\end{array}$ & 15 & 60.00 & - Pedagogy & $\begin{array}{l}\text { - Lack pedagogical and technological } \\
\text { skills to draw student attention and } \\
\text { facilitate discussion, CW and } \\
\text { comprehension }\end{array}$ \\
\hline & & & & $\begin{array}{l}\text { - } \\
\text { Collaboration/di } \\
\text { scussion/interac } \\
\text { tion/participati } \\
\text { on }\end{array}$ & $\begin{array}{l}\text { - Failed to generate student } \\
\text { motivation and self-regulation }\end{array}$ \\
\hline $\begin{array}{l}\text { Instructional } \\
\text { delivery }\end{array}$ & - & - & - & - & - \\
\hline \multirow[t]{2}{*}{ Assessment } & $i 6, i 10$, i15 & 3 & 12.00 & - Feedback & $\begin{array}{l}\text { - Not knowing how to give online } \\
\text { feedback }\end{array}$ \\
\hline & & & & - Plagiarism & $\begin{array}{l}\text { - Not knowing how to deal with } \\
\text { student's writing dishonesty }\end{array}$ \\
\hline
\end{tabular}

Table 5 reveals four emerging categories of challenges: student engagement $(60.00 \%)$, learning environment (16.00\%), instructional planning (12.00\%) and assessment (12.00\%). The results demonstrate that the majority of the instructors perceived that student engagement was the biggest challenge for them. The findings are consistent with those of Whitney (2019), who found that instructors who teach large classes tend to use the lecture-only approach and it gradually creates passive students who may not engage in the learning process and misbehave.

\subsection{Instructors' SCW teaching practices}

The classroom observation checklist results (Table 6) reveal problems of SCW teaching in four aspects. Regarding the expected practices, the instructors conducted online writing assessments at a poor level (41.25\%), which was the lowest percentage of all the aspects of their teaching practices, followed by student engagement, which was at a sufficient level of $58.75 \%$. 
Table 6. Levels of the instructors' SCW teaching practices based on the observation checklist

\begin{tabular}{ccc}
\hline Categories & Percentage & Meaning \\
\hline Learning environment & 81.25 & Very good \\
Student engagement & 58.75 & Sufficient \\
Instructional delivery & 70.00 & Good \\
Assessment & 41.25 & Poor \\
\hline Overall & 62.81 & Satisfactory \\
\hline
\end{tabular}

The field notes provide specific details supporting quantitative results as shown in Table 7.

Table 7. Instructors' practices based on the field notes

\begin{tabular}{lll}
\hline Core categories & Sub-categories & Description of challenges \\
\hline Learning environment & - Teacher-centred environment & - Teacher-dominant instruction \\
Student engagement & - Pedagogy & - Non-interactive lectures \\
& & - Little CW facilitation \\
Instructional delivery & - Technical issues & - Inactive learning activities \\
Assessment & - Feedback & - Lack of technical support \\
& & - Asking low-level questions \\
& & - Lack of peer feedback activities \\
& - Not providing ongoing feedback \\
\hline
\end{tabular}

The interview results indicate that the instructors rated their knowledge and skills in teaching online English writing from five to eight. To illustrate, Instructors 2 and 3's answers are as follows:

I do not prefer to teach online. Only some students have interactions with me. Most of them turned off their cameras and when I asked a question, they were not there, they disappeared. (Instructor 2)

To be honest, I'm not confident about my English writing. On top of that, I'm not confident about using technology in teaching, especially when I have to integrate technologies into my instruction. I think I have to be skilful in technology integration to teach well. (Instructor 3)

Their answers show a low sense of teaching efficacy and a need for instructional technology training. The findings lend support to Denniston's (2020) acknowledgement of burnout in higher education as a cause of low performance among online instructors. The findings are also in line with those of Alford (2019), who found that instructors' English proficiency and teaching experience have an impact on their confidence to teach writing.

For instructional planning, they prepared their online lessons based on the course description and the textbook provided by the programme, which was similar to their traditional classroom lessons.

... I follow the activities given in the textbook. For the online class, the PowerPoint in each chapter and the PDF files provided on the textbook are shown on the online screen in order to stimulate and engage the class to pay attention to the lessons and at the end of each chapter, the assignment will be given in order to evaluate the content of the lessons. (Instructor 5) 
For the learning environment and student engagement, the instructors did not report problems. For instructional delivery, the instructors' responses indicate a lack of media literacy to deal with technology failure and to provide a variety in content delivery.

... I think PowerPoint presentation is students' guideline to study both via online instruction and offline instruction. They can learn by themselves after class. I left PowerPoint files into the Microsoft Teams. (Instructor 5)

For assessment, the instructor's primary focus was on evaluating students' written products and rarely on their writing process and progress.

I grade students' writing according to the given rubric from the course coordinator. (Instructor 4)

Surprisingly, many studies (e.g., Al-Nofaie, 2020; Steinberger, 2017; Yim \& Warschauer, 2017) raised the computer-related problems; the present study found that the instructors were likely to neglect the issue and shift the focus onto teaching pedagogy and technology integration.

\subsection{Proposed solutions to the challenges of online EFL writing instruction}

\subsubsection{Student engagement}

It was found in this study that student engagement was the most serious problem for the participant instructors, leading to a conclusion that instructors lack skills to stimulate active learning in the SCW classroom. Their instruction may be effective if they create a relaxing classroom environment and select a learning platform that allows students to easily communicate and co-author with peers. Instructors should observe and monitor students while doing a writing assignment and encourage students to give and receive constructive feedback to/from their peers. Moreover, it was found that the instructors failed to promote dialogic engagement using a variety of teacher pedagogical dialogues, so instructors should ask thought-provoking questions while teaching and provide ongoing, constructive and specific feedback regarding students' writing (Whitney, 2019). Since technologies can be used to promote reflection on writing, learning community, interaction and writing motivation (Zhang \& Zou, 2021), instructors may use an LMS and other digital environments to provide more opportunities for classroom interactions, such as peer reviews and editing (CCCC, 2013).

\subsubsection{Goals}

Students' goals play a significant role in their contribution to SCW (Kitjaroonchai \& Suppasetseree, 2021). Realistic, clear, concise and measurable goals are necessary for developing specific learning objectives and assessments. Instructors should convey the idea that learning some knowledge and procedures is not the goal of SCW instruction, but rather mastery of SCW is a means for them to apply it in their profession. Instructors should always connect students' knowledge, experiences and interest with their writing goals (Parkinson \& Dinsmore, 2019). In addition, students should be encouraged to use technology to set shared, achievable goals with their group members for completing their writing tasks. 


\subsubsection{Content}

Since English proficiency, skills in teaching writing and instructional technology skills are crucial for online writing instruction (CCCC, 2013), instructors should have essential English writing knowledge and be able to deliver it through an online synchronous mode. The instructors in this study appeared to be worried about students' diverse English proficiency and online task design, so the type of content and tasks should be determined to be appropriate to a synchronous learning mode and be sequenced for logical learning according to a level of difficulty, familiarity, interest and development.

\subsubsection{Tools}

The instructors perceived a lack of media literacy and technical skills as a major obstacle for them to teach SCW, so selecting effective tools is important. Instructional tools, communication tools and assessment tools are needed in the SCW classroom. There are free web conferencing tools that can be used to facilitate online SCW instruction, such as CiscoWebex, Google Meet, Microsoft Teams and Zoom. In addition, an LMS is needed for SCW classroom management (Ustun et al., 2021). A rubric should be used to provide a transparent assessment of students' writing performance. Text mining tools should be used to evaluate the level of student engagement in SCW and instructors can assess and increase the degree of interaction of each group member (Yim \& Warschauer, 2017).

\subsubsection{Classroom management strategies}

The analysis indicates that the instructors struggle to manage large class sizes and students' improper online behaviours; so, particular SCW rules or guidelines should be developed with students' input and reviewed or changed as necessary; for example, a rule concerning students' privacy (Steinberger, 2017). It was also found that instructors appeared to have difficulties in establishing a collaborative environment. Thus, instructors should inform their students that they are required to exchange ideas, make comments or ask questions that are relevant to the lessons during group discussions. Instructors should also assign students to breakout rooms during class sessions to complete group writing tasks throughout the pre-writing, writing and post-writing stages of the writing process (Krishnan et al., 2019).

\subsubsection{Instructor and students' roles}

It was found in this study that the instructors were likely to operate a teacher-centred environment with non-interactive lectures and inactive learning activities. It is suggested that instructors play the roles of coach and facilitator (Krishnan et al., 2019). Instructors should provide adequate pre-writing tasks to establish group cohesion, integrate various collaboration tasks and support guided instruction at the beginning of each task, help students build a sense of community by staying with the same writing team members (Dahmash, 2021) and use CW to prepare students for subsequent individual writing. The roles of students are that they actively engage in group writing activities and share responsibility for writing outcomes.

\subsubsection{SCW activities}

The results indicate that the instructors lack pedagogical and technological skills to stimulate active leaning activities, leading to poor collaboration. Thus, effective SCW activities should enable students to engage, interact and collaborate with their peers. Instructors should employ a variety of synchronous learning technologies and pedagogies in pre-, while and post-writing activities to provide students sufficient opportunities to improve their English writing proficiency (Li, 2018). However, it is important 
to keep in mind that instructors and students do not have to be technology experts to be successful in an online SCW course (CCCC, 2013).

\subsubsection{Assessment}

SCW assessment appears to be one of the most problematic areas for the instructors because they practiced product-oriented assessments and lack skills to provide appropriate response to group writing. This may lead to students' complaints, unfair work contribution and low engagement (Coffin, 2020). Therefore, instructors should assess group and individual written products, the writing process and individual writing progress. For written products, the quality and quantity of collaborative text and the amount of each student's textual contribution should be evaluated by using a criterion-referenced e-rubric (Erguvan \& Aksu, 2021). For the writing process and progress, instructors should monitor and assess regularly by using the data collected from text mining tools (Yim \& Warschauer, 2017). Formative assessments, such as asking critical questions, interviewing students and their peers and observing students doing group work will enable instructors to provide ongoing positive or corrective feedback that is specific and appropriate to students' writing development.

\section{Conclusion and recommendations}

This study explored the challenges that EFL writing instructors were confronting while teaching synchronous online English writing. The scope of the exploration included teaching self-efficacy, instructional planning, learning environment, student engagement, instructional delivery and assessment. The data collection was carried out with EFL writing instructors from 15 universities in Thailand. Even though the analysis of data demonstrated some problems in SCW instruction, these problems could not be generalised beyond Thai instructors and contexts involved in this study.

The rating scale survey results present that the instructors perceived student engagement and teaching self-efficacy as the most problematic issues, and the least problematic ones were instructional planning and learning environment. On the other hand, the most mentioned problems in the openended survey fell into assessment and instructional planning with the same proportion of $12 \%$.

The classroom observations provide similar results to the open-ended answers that instructors were rather weak at online assessment and student engagement. Surprisingly, the interviews reveal that, of all the four aspects of challenges that the instructors presented, teaching self-efficacy was the greatest challenge that had a strong impact on their SCW teaching practices.

Therefore, engaging students in the classroom, integrating technologies in teaching and doing online assessments are major challenges of incorporating SCW in an online writing course for inexperienced EFL instructors. To improve the quality of teaching, it is suggested that instructors incorporate student engagement, goals, content, tools, classroom management strategies, instructor and students' roles, SCW activities and transparent assessment in their instructional design. Equally important is that EFL instructors need technological support and pedagogical guidelines for SCW instruction. In addition, without consistent access to high-speed Internet, students will not fully benefit from their teaching.

This study reveals challenges of SCW instruction from the point of view of EFL writing instructors. Considerations of these difficulties and their solutions would be of great benefit to SCW lesson planning. At the level of curriculum design, it is suggested that instructors focus on creating and maintaining 
interaction and student engagement, which will improve students' attitudes, motivation and achievement. Language policy planners can consider solutions to SCW teaching problems for developing successful cyber education in EFL contexts.

This study was limited to EFL instructors in one country. Further research employing a similar design and larger sample size would be interesting. Besides, this study has revealed difficulties that writing instructors perceive as barriers to their SCW teaching. Further research could apply this knowledge to develop guidelines or an instructional model to facilitate university EFL instructors' instructional design.

\section{References}

Abrams, Z. I. (2019). Collaborative writing and text quality in Google Docs. Language Learning \& Technology, 23(2), 22-42. https://doi.org/10125/44681

Adara, A. R., \& Onin, N. (2020). Analysis on the differences in EFL learners' demotivating factors after COVID-19 pandemic. Ta'dib, 23(2), 225-236. https://doi-org.proxy.library.mfu.ac.th/10.31958/jt.v23i2.2373

Alahmari, A. A. (2019). A mixed methods study of the implementation of collaborative technology tools for enhancing collaboration and student engagement in online learning: Faculty experiences and student perspectives. http://doi.org/10.30707/ETD2019.Alahmari.A

Alford, K. (2019). Writing together: A study of secondary ELA preservice teachers participating in peer writing communities (Doctoral dissertation). Arizona State University. https://core.ac.uk/download/pdf/200249679.pdf

Alghamdi, A. K. H., El-Hassan, W. S., Al-Ahdal, A. M. H., \& Hassan, A. A. (2021). Distance education in higher education in Saudi Arabia in the post-COVID-19 era. World Journal on Educational Technology: Current Issues, 13(3), 485-501. https//:doi.org/10.18844/wjet.v13i3.5956

Al-Nofaie, H. (2020). Saudi university students' perceptions towards virtual education during COVID-19 pandemic: A case study of language learning via blackboard. Arab World English Journal, 11(3), 4-20. https://dx.doi.org/10.24093/awej/vol11no3.1

Alwahoub, H. M., Azmi, M. N. L., \& Halabieh, M. (2020). Computer-assisted collaborative writing and students' perceptions of Google Docs and wikis: A review paper. Language Literacy: Journal of Linguistics, Literature, and Language Teaching, 4(1), 15-27. https://doi.org/10.30743/ll.v4i1.2499

Bao, W. (2020). COVID-19 and online teaching in higher education: A case study of Peking University. Human Behavior and Emerging Technologies, 2(2), 113-115. https://doi.org/10.1002/hbe2.191

Brown, J. D. (2001). Using surveys in language programs. Cambridge University Press.

CCCC (Committee for Best Practices in Online Writing Instruction). (2013). A position statement of principles and example effective practices for online writing instruction (OWI). http//:www.ncte.org/cccc/resources/positions/owiprinciples

Cho, H. Y. (2021). Factors mediating small-group interactions during synchronous web-based collaborative summary writing using Google Docs. In M. P. Garcia Mayo (Ed.), Working collaboratively in second/foreign language learning (pp. 249-274). De Gruyter Mouton. https://doi.org/10.1515/9781501511318-011

Coffin, P. (2020). Implementing collaborative writing in EFL classrooms: Teachers and students' perspectives. LEARN Journal: Language Education and Acquisition Research Network, 13(1), 178-194. https://so04.tcithaijo.org/index.php/LEARN/article/view/237844/162849 
Cohen, J. A. (1960). Coefficient of agreement for nominal scales. Educational and Psychological Measurement, 20, 37-46. https://doi.org/10.1177/001316446002000104

Creswell, J., \& Poth, C. N. (2016). Qualitative inquiry and research design: Choosing among five approaches. Sage.

Dahmash, N. B. (2021). Synchronous and asynchronous English writing classes in the EFL context: Students' practices and benefits. Arab World English Journal, 12(2), 93-108. Database: Complementary Index. https://doi.org/10.24093/awej/vol12no2.7

Denniston, N., J. (2020). A predictive analysis of online teaching self-efficacy and engagement in recovery experiences of post-secondary online faculty. (Doctoral dissertation). Grand Canyon University. https://www.proquest.com/openview/a5aed6685339abc182caebb8bcecbd5f/1?pqorigsite $=$ gscholar $\& \mathrm{cbl}=18750 \&$ diss $=\mathrm{y}$

Erguvan, I. D., \& Aksu D. B. (2021). Gathering evidence on e-rubrics: Perspectives and many facet Rasch analysis of rating behaviour. International Journal of Assessment Tools in Education, 8(2), 454-474. https://doiorg.proxy.library.mfu.ac.th/10.21449/ijate.818151

Kitjaroonchai, N., \& Suppasetseree, S. (2021). A case study of ASEAN EFL learners' collaborative writing and small group interaction patterns in Google Docs. English Language Teaching, 14(5), 89-108. https://doi.org/10.5539/elt.v14n5p89

Krishnan, J., Yim, S., Wolters, A., \& Cusimano, A. (2019). Supporting online synchronous collaborative writing in the secondary classroom. Journal of Adolescent and Adult Literacy, 63(2), 135-145. https://doi.org/10.1002/jaal.871

Li, M. (2018). Computer-mediated collaborative writing in L2 contexts: An analysis of empirical research. Computer Assisted Language Learning, 31(8), 882-904. https://doi.org/10.1080/09588221.2018.1465981

Ma, K., Chutiyami, M., Zhang, Y., \& Nicoll, S. (2021). Online teaching self-efficacy during COVID-19: Changes, its associated factors and moderators. Education and Information Technologies, 1-23. https://doi.org/10.1007/s10639-021-10486-3

Ministry of Education (Thailand). (2015). Announcement of the Ministry of Education. http://www.mua.go.th/users/bhes/front home/criterion58/criterion\%20 m58.PDF

Murphy, M. P. A. (2020). COVID-19 and emergency eLearning: Consequences of the securitization of higher education for post-pandemic pedagogy. Contemporary Security Policy, 41(3), 492-505. https://doi.org/10.1080/13523260.2020.1761749

Noor, S., Isa, F. Md., \& Mazhar, F. F. (2020). Online teaching practices during the COVID-19 pandemic. Educational Process International Journal, 9(3), 169-184. http://dx.doi.org/10.22521/edupij.2020.93.4

Olesen, M. (2020). Cooperative collaboration in the hybrid space of Google Docs based group work. Education Sciences, 10(269), 1-13. https://doi/10.3390/educsci10100269

Ozdal, R. Y., Yukselir, C., \& Akarsu, O. (2021). Foreign language learners 'perceptions and preferences of synchronous and asynchronous online language learning during COVID-19 pandemic. Journal of Social Sciences Institute, 25(2), 699-715. https://dergipark.org.tr/tr/download/article-file/1655815

Parkinson, M. M., \& Dinsmore, D. L. (2019). Understanding the developmental trajectory of second language acquisition and foreign language teaching and learning using the model of domain learning. System. https://doi.org/10.1016/i.system.2019.102125

Rovinelli, R. J., \& Hambleton, R. K. (1977). On the use of content specialists in the assessment of criterionreferenced test item validity. Dutch Journal of Educational Research, 2, 4-60. https://files.eric.ed.gov/fulltext/ED121845.pdf 
Sarkhosh, M., \& Najafi, S. (2020). Collaborative and individual writing: Effects on accuracy and fluency development. Porta Linguarum, 27-42. https://www.ugr.es/ portalin/articulos/PL numero33/2 Mehdi\%20Sarkhosh.pdf

Sriwichai, C., \& Inpin, B, (2018). The effectiveness of the writing instructional model based on blended and selfdirected learning on promoting student's writing ability and self-directed learning. Journal of Education, 29(3), 32-56. https://so01.tci-thaijo.org/index.php/AJE/article/view/180430

Steinberger, F. (2017). Synchronous collaborative L2 writing with technology (Doctoral dissertation). Ludwig Maximilian University of Munich. https://doi.org/10.5282/edoc.21677

Storch, N. (2013). Collaborative writing in L2 classrooms. Multilingual Matters.

Storch, N. (2019). Collaborative writing. Language Teaching, 52(1), 40-59. https://doi.org/10.1017/S0261444818000320

Sugino, C. (2021). Student perceptions of a synchronous online cooperative learning course in a Japanese women's university during the COVID-19 pandemic. Education Sciences, 11(5), 231. https://doi.org/10.3390/educsci11050231

Ustun, A. B., Karaoglan, Y. F. G., \& Yilmaz, R. (2021). Investigating the role of accepting learning management system on students' engagement and sense of community in blended learning. Education \& Information Technologies, 26(4), 4751-4769. https://doi-org.proxy.library.mfu.ac.th/10.1007/s10639-021-10500-8

Whitney, M. (2019). Synchronous cloud instruction. Proceedings of the Twenty-fifth Americas Conference on Information Systems (AMCIS). https://dblp.org/db/conf/amcis/amcis2019.html

Wilkinson, D., \& Birmingham, P. (2003). Using research instruments: A guide for researchers. Routledge. https://doi.org/10.4324/9780203422991

$\mathrm{Xi}$, L., \& Li, G. (2020). Students' sense of community and perspectives of taking synchronous and asynchronous online courses. Asian Journal of Distance Education, 15(1), 169-179. https://doi.org/10.5281/zenodo.3881614

Yim, S., \& Warschauer, M. (2017). Web-based collaborative writing in L2 contexts: Methodological insights from text mining. Language Learning \& Technology, 21(1), 146-165. http://hdl.handle.net/10125/44599

Zhang, R., \& Zou, D. (2021). Types, features, and effectiveness of technologies in collaborative writing for second language learning. Computer Assisted Language Learning, 1-31. https://doi.org/10.1080/09588221.2021.1880441 